\title{
Functional and cosmetic results of a lower eyelid crease approach for external dacryocystorhinostomy
}

\author{
Resultados cosméticos e funcionais na dacriocistorrinostomia com incisão transpalpebral \\ Patricia Mitiko Santello Akaishi ${ }^{1}$, Juliano Borges Mano ${ }^{1}$, Ivana Cardoso Pereira ${ }^{1}$, Antonio Augusto Velasco e Cruz ${ }^{1}$
}

\begin{abstract}
Purpose: External dacryocystorhinostomy is routinely performed through a cutaneous vertical incision placed on the lateral aspect of the nose. The lower eyelid crease approach has been seldom reported. The purpose of this study is to report the cosmetic and functional results of the lid crease approach for external dacryocystorhinostomy in a series of patients.

Methods: Prospective, interventional case series. Twenty-five consecutive patients (17 women) ranging in age from 3 to 85 years (mean \pm SD $=44.84 \pm 23.67$ ) were included in the study. All patients but one underwent unilateral external dacryocystorhinostomy with a 10 to $15 \mathrm{~mm}$ horizontal incision placed on a subciliary relaxed eyelid tension line. The inner canthus was photographed with a Nikon D70S digital camera with a macrolens and resolution of $3008 \times 2000$ pixels at 1, 3 and 6 months after surgery. The resulting scar was judged from the photographs by 3 observers (ophthalmologist, plastic and head and neck surgeons) according to a four level scale ( $1=$ unapparent, $2=$ minimally visible, $3=$ moderately visible, $4=$ very visible).

Results: The surgery was easily performed in all patients with a $90.48 \%$ success. Three of the elderly patients (ages 61,79 and $85 \mathrm{yr}$ ) developed mild lacrimal punctum ectropion, which resolved with conservative treatment. One patient had a hypometric blink which spontaneously recovered within one month. The mean score for scar visibility was 2.19 ( $\left.1^{\text {st }} \mathrm{mo}\right), 1.65$ ( $\left.3^{\text {th }} \mathrm{mo}\right)$ and $1.44\left(6^{\text {th }} \mathrm{mo}\right)$.

Conclusions: The eyelid crease approach is an excellent option for external dacryocystorhinostomy. It leaves an unapparent scar since the first month after surgery, even in younger patients. The functional results are excellent and comparable to other techniques. Care should be taken in elderly patients with lower eyelid laxity in order to prevent lacrimal punctum ectropion.
\end{abstract}

Keywords: Dacryocystorhinostomy/methods; Eyelids/surgery; Cicatrix/prevention \& control; Lacrimal apparatus/surgery; Humans

\begin{abstract}
RESUMO
Objetivos: A dacriocistorrinostomia externa é classicamente realizada por meio de incisão cutânea nasal. Há poucos relatos sobre a incisão transpalpebral, posicionada no sulco infraciliar da pálpebra inferior. O presente estudo tem por objetivo relatar os aspectos cosméticos e funcionais utilizando a técnica transpalpebral.

Métodos: Série de casos, intervencional e prospectivo. Foram incluídos 25 pacientes consecutivos (17 mulheres) com idades variando de 3 a 85 anos (média $\pm d p=44,84 \pm 23,67$ ), que apresentavam dacriocistite crônica. A dacriocistorrinostomia foi unilateral em 24 casos e bilateral em 1 caso. A incisão transpalpebral foi posicionada no sulco infraciliar medial, com extensão de 10 a $15 \mathrm{~mm}$. Foram realizadas fotografias digitais do canto interno (Nikon D70S, lente macro, resolução de 3008 × 2000 pixels) nos tempos pós-operatórios 1, 3 e 6 meses. A visibilidade da cicatriz foi avaliada por 3 observadores (oftalmologista, cirurgião plástico e cirurgião de cabeça e pescoço) utilizando a seguinte escala: $1=$ imperceptível, 2= minimamente visivel, $3=$ moderadamente visivel, $4=$ muito visivel.

Resultados: ADCRfoirealizada sem dificuldades ecom sucesso funcionalem $90,48 \%$ dos casos. A pontuação média para visibilidade da cicatriz foi de 2,19 (1ํㅡês), 1,65 (3ํำês) e 1,44 (6-mês). Houve 3 casos de ectrópio leve do ponto lacrimal que foram tratados conservadoramente. Um paciente apresentou piscar espontâneo incompleto, com resolução no primeiro mês de pós-operatório.

Conclusão: A incisão transpalpebral é uma excelente via de acesso para realização da dacriocistorrinostomia. A cicatriz é pouco visível desde o primeiro mês após a cirurgia, mesmo em pacientes maisjovens. Os resultados funcionais säosemelhantes ao das outras técnicas. Em pacientes mais idosos é necessário avaliação cuidadosa da frouxidão palpebral a fim de evitar a indução de ectrópio lacrimal.
\end{abstract}

Descritores:Dacriocistorrinostomia/métodos; Pálpebras/cirurgia;Cicatriz/prevenção\& controle; Aparelho lacrimal/cirurgia; Humanos

\section{INTRODUCTION}

Since the twenties when Dupuy-Dutemps and Bourguet published their external dacryocystorhinostomy (DCR) technique the surgery has been performed, with slight variations, with the same type of vertical incision on the lateral aspect of the nose ${ }^{(1)}$. Harris, in 1989, was the first to demonstrate that external DCR can also be done with a horizontal incision placed on a lower lid crease ${ }^{(2)}$. In this study, we evaluated the cosmetic functional results of lower lid incision for external DCR.

\section{METHODS}

This prospective interventional case series included 25 consecutive patients (26 surgeries) with nasolacrimal duct obstruction.
The sample consisted of 17 female and 8 male ranging in age from 3 to 85 years (mean \pm SD $=44.84 \pm 23.67$ ). We did not include any patient with scars in the medial cantal area. One patient with a failed endonasal DCR and dilated lacrimal sac was included in the study. All patients underwent external DCR (1 bilateral) through the lower eyelid.

During the postoperative period the medial cantus of all patients was photographed at a 30-degree angle at 1, 3 and 6 months after surgery. A medical photographer using a digital Nikon D70S camera equipped with a macrolens and a built-in flash took all pictures. The resolution of the images was kept constant at $3008 \times 2000$ pixels. The images of each patient were shown to 3 observers (an ophthalmologist, a general plastic surgeon and a head and neck specialist) on a 22-inch computer monitor with a screen resolution
Funding: No specific financial support was available for this study.

Disclosure of potential conflicts of interest: P.M.S.Akaishi, None; J.B.Mano, None; I.C.Pereira, None; A.A.V.Cruz, None.

Correspondence address: Patricia M. S. Akaishi. Department of Ophthalmology, Otorhinolaryngology and Head and Neck Surgery; School of Medicine of Ribeirão Preto, University of São Paulo, Hospital das Clínicas-Campus - Av. Bandeirantes 3900 - Ribeirão Preto (SP) - 14049-900 Brazil -Email: patriciamitiko@gmail.com 


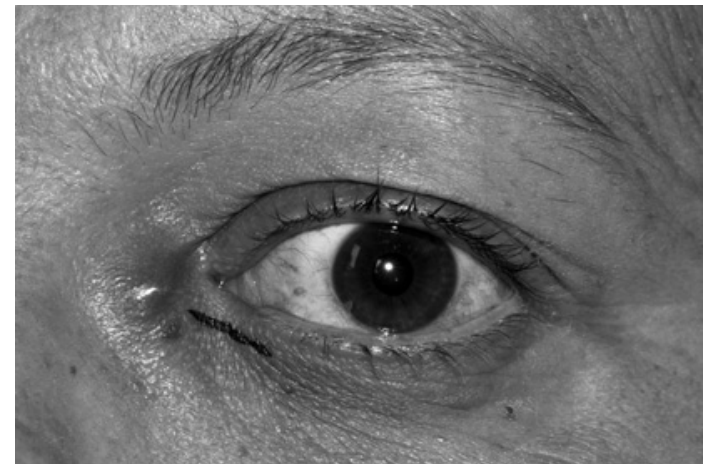

Figure 1. Subciliary incision placed on a medial lower lid crease.

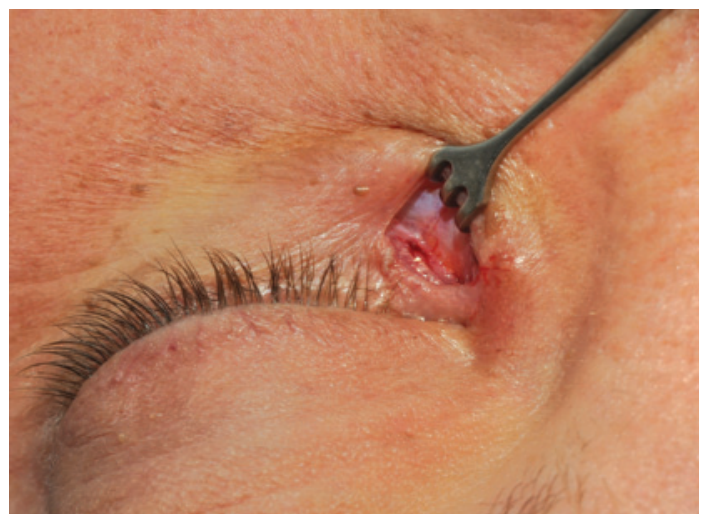

Figure 2. Myocutaneous dissection.

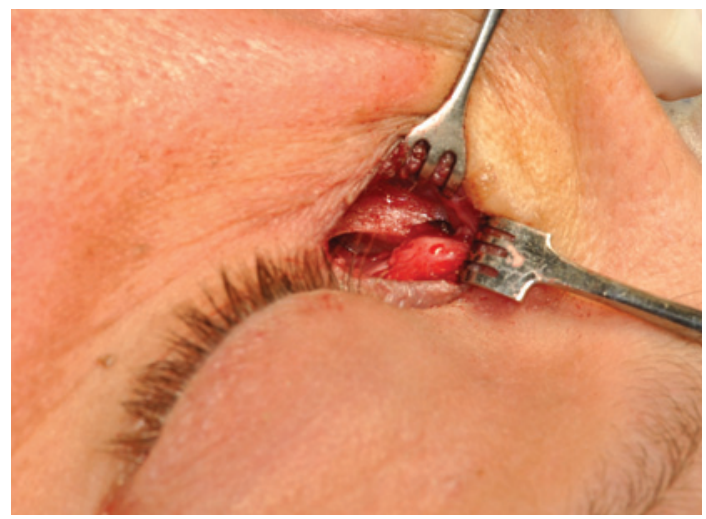

Figure 3. Exposure of theanteriorlacrimal crestand proximal nasolacrimal duct. The lacrimal sac was opened to facilitate the exposure. of $1680 \times 1050$ pixels. The location of the incision was shown to the observers who were then instructed to grade the appearance of the scar using the following 4-level scale: 1-invisible, 2- minimally visible, 3-moderately visible, and 4- very visible.

The scores were averaged and one-way analysis of variance (ANOVA) was employed to compare the scores at the different times during the postoperative period.

\section{SURGICAL TECHNIQUE}

The incision was fashioned in a medial relaxed skin lower lid tension line. The total length of incision ranged from 10 to $15 \mathrm{~mm}$ (Figure 1). Local anesthesia with 2\% lidocaine plus 1:100.000 epinephrine provided good homeostasis, which is important in order to avoid excessive cauterization. A myocutaneous dissection (Figure 2) was carried out inferomedially until complete exposure of the anterior lacrimal crest (Figure 3). The lacrimal sac and proximal nasolacrimal duct were exposed. The surgery then proceeded as usual. The skin was closed with 3 to 4 interrupted 6-0 nylon sutures. The muscle plane was not sutured.

\section{RESULTS}

Functional success, expressed by positive irrigation after 6 months of follow-up, occurred in $90.48 \%$ of cases. Three elderly patients (61 to $85 \mathrm{yr}$ ) developed mild lacrimal ectropion after surgery, which improved in all patients within a few weeks after conservative treatment with corticosteroid cream massage. One patient developed a hypometric blink without lagophthalmos or keratopathy, which spontaneously resolved within the first postoperative month.

The mean scores for scar appearance were: 2.19 at one month, 1.65 at 3 months and 1.44 at 6 months after surgery (Figure 4). ANOVA revealed significant differences in scar appearance between time points. ( $F=10.11, p=0.0001)$. Post-hoc Tukey tests revealed that the scores did not differ between 3 and 6 months but both differed from the one month score.

\section{DISCUSSION}

Our findings concur well with previous studies concerning the cosmetic aspect of the scar with lower eyelid incision for $D C R^{(2,3)}$. Lower lid relaxed skin tension lines are horizontal and incisions placed on these lines are hardly noticeable shortly after surgery. Although the classical nasal incision may also provide excellent cosmetic results ${ }^{(4,5)}$, we believe that the lower eyelid approach has some advantages over the classical nasal incision. The dissection is in the lower eyelid minimizing the bleeding, there is no concern about angular vessels lesions, the lacrimal sac is approached from below at the nasolacrimal duct entrance and the osteotomy site is thus quite low preventing any degree of stump syndrome. There is
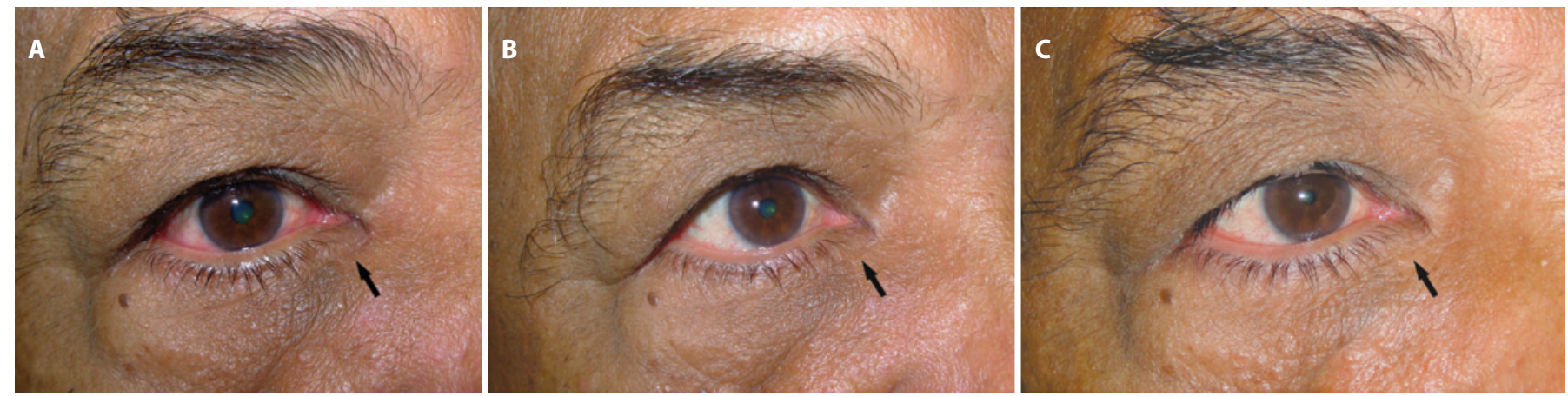

Figure 4. Postoperative appearance of the surgical scar (arrows) at 1 month (A), 3 months (B), and 6 months (C). 
no need to detach the medial canthal tendon, which is left undisturbed. Finally, as the nose is not manipulated the patients are able to wear glasses immediately after surgery.

We did not experience any technical problems during the surgery. As is the case for the classical approach, all surgeries were performed with just one surgical assistant. Contrary to Putterman's point of view, we do not think that there is any need for special equipment to safely perform the operation ${ }^{(6)}$.

The few complications we have encountered were related to lower lid laxity. In elderly patients care should be taken during closure in order to avoid lacrimal ectropion. In our patients this complication was temporary and did not require any surgical correction.

\section{REFERENCES}

1. Dupuy-Dutemps B. Procédé plastique de dacryocysto-rhinostomie et ses résultats. Ann Oculistique. 1921:241-61.

2. Harris GJ, Sakol PJ, Beatty RL. Relaxed skin tension line incision for dacryocystorhinostomy. Am J Ophthalmol. 1989;108(6):742-3.

3. Kim JH, Woo KI, Chang HR. Eyelid incision for dacryocystorhinostomy in Asians. Korean J Ophthalmol. 2005;19(4):243-6.

4. Devoto MH, Zaffaroni MC, Bernardini FP, de Conciliis C. Postoperative evaluation of skin incision in external dacryocystorhinostomy. Ophthal Plast Reconstr Surg. 2004:20(5):358-61.

5. Sharma V, Martin PA, Benger R, Kourt G, Danks JJ, Deckel Y, et al. Evaluation of the cosmetic significance of external dacryocystorhinostomy scars. Am J Ophthalmol. 2005;140(3):359-62.

6. Putterman AM. Eyelid incision approach to dacryocystorhinostomy facilitated with a mechanical retraction system. Am J Ophthalmol. 1994;1 18(5):672-4.

\title{
$14^{\circ}$ Congresso de Oftalmologia USP e $13^{\circ}$ Congresso de Auxiliar de Oftalmologia
}

\author{
$\mathbf{2 5}$ e $\mathbf{2 6}$ de novembro de 2011 \\ Centro de Convenções Rebouças \\ São Paulo - SP
}

\section{Informações:}

JDE Organização de Eventos

Tels.: (11) 5084-9174 e 5082-3030

Site: http://www.oftalmologiausp.com.br 